\title{
Entering into a community-university collaboration: Reflections from the Whole Community Project
}

\section{FoodDignity}

\author{
E. Jemila Sequeira* \\ Former director, Whole Community Project
}

Submitted May 19, 2018 / Published online July 18, 2018

\begin{abstract}
Citation: Sequeira, E. J. (2018). Entering into a community-university collaboration: Reflections from the Whole Community Project. Journal of A griculture, F ood Systems, and C ommunity D evelopment, 8(Suppl. 1), 9-11. https:// doi.org/ 10.5304/ jafscd.2018.08A .014
\end{abstract}

Copyright @ 2018 by the Author. Published by the Lyson Center for Civic Agriculture and Food Systems. Open access under CC BY license.

W hen asked to tell the story of how and why I was invited and decided to join the Food Dignity research project, I found myself traveling back over a long road full of unexpected turns, bumps, discoveries, and delights. And as I began to reflect over the five years spent implementing that project in Tompkins County, New York, I was once more awed by the countless stories to be told and knew that, at best, I could offer merely a glimpse of the wonderful and challenging experiences that were ultimately instrumental in learning valuable lessons for cultivating sustainable food systems. In sharing the process and results of being part of such a unique opportunity, I hope to both inspire and challenge readers to explore the possibilities that can exist when the sustainability of our food systems places a high value on everyone experiencing "dignity" in their relationship to food-whether as a consumer, entrepreneur,

\footnotetext{
* E. Jemila Sequeira, former director of Whole Community Project in Cornell Cooperative Extension, Tompkins County (http:/ / ccetompkins.org), Ithaca, New Y ork USA; mattersofdignity@gmail.com
}

farmer, composter, or activist.

The name for this project, Food Dignity, came about during one of the many conversations I had with D r. Christine Porter in the early days of the project's development work. We often went back and forth sharing ideas about just about everything concerning food. While our conversations were frequently intermingled with heroic ambitions, unbridled venting, fear-based doubts, and recycled analysis, something was different about this conversation. When Christine asked, "what does it take to make the food system work for everyone?", the first thing that came to my mind was dignity- isn't this all about dignity? Within the context of the Food Dignity project I use dignity to describe what I believe should be an intrinsic right of all humans. I believe food dignity is reflected in one's ability to experience respect and equal access to means of knowledge, resources, authority, and power in order to influence and make informed decisions on all food-related issues-including the foods available for us to put on our own plates, what's served in schools, or how zoning affects small- 
scale farm development.

It was exciting and terrifying to have years of frontline work on community food issues rolled into a formal community-university collaborative research project. I was excited because I saw possibilities. I was terrified of having to navigate through a federal U.S. D epartment of Agriculture (USD A) grant and having to work within a powerfully academic environment. It was terrifying because I didn't know what the rules were. I certainly had a lot to learn. But, I was excited because I was beginning to see that various parts of my life were coming together to fulfill an unusual role that had great meaning not just for me, but for the people on whose behalf I'd been working for so long, and for a transformative vision of the food system that could pave the way toward achieving a vital part of social justice.

Two events will always be memorable for me along this five-year journey: the first time I met Christine Porter in 2007, when she asked to interview me for her Cornell graduate research on the relationship between health disparities and food justice; and when I learned the Food D ignity research proposal was awarded.

Talking with Christine during that first interview is when I learned about the emerging food activist movement. The interview questions and information resonated with my work at a small nonprofit where I served as the director of outreach to the medically underserved community. It was quite a surprise when only a year later I would be employed at Cornell Cooperative Extension of Tompkins County (CCETC) and find myself working with Christine, who was doing her $\mathrm{PhD}$ at Cornell University at that time and was working closely with CCETC. When the Food Dignity project came along three years later, I saw it as an excellent framework to deepen our earlier conversation, work, and research.

By the time the Food Dignity project was underway, I'd spent decades in a variety of frontline roles as a service provider and activist on behalf of people living with poverty, health challenges, and a plethora of consequences bearing down on them as the result of the vast spectrum of socially sanctioned oppressions rendering them marginalized and disenfranchised. Taking on a leading role in one of the project's five community partner sites, I faced a huge learning curve as I delved into research about food systems, including its relationship with and responsibility to address food insecurity. As the academy released a plethora of scientific research on obesity, diabetes, and other chronic health conditions, the research data on demographics revealed disturbing and compelling evidence highlighting the relationship between people with chronic health conditions and their relative inaccessibility to fresh, healthy, and affordable food in their communities.

While I was informed and motivated by this sudden flood of formally gathered and disbursed information, I wasn't entirely comfortable with its format. The science and analysis behind my life's work on behalf of individual and community health seemed to stand apart from the reality of people's lives as I had come to understand them, and had in many ways lived them myself. Even now, as I think about everything I learned as the result of becoming part of the Food Dignity research project, it's the life stories that continue to carry the most important lessons.

It was humbling to watch at a distance as people arrived to stand in line waiting for the food pantry to open the door; many would arrive an hour early to make sure they could get the best selections of donated foods. Many frequented the pantries as "regulars" and were dependent upon food pantries to feed themselves or their family. Emergency pantries are an absolute necessity in crisis situations, but regular dependence on emergency pantries doesn't provide healthy sustainability for anyone.

I'll never forget the stories I heard from people while they waited in line at the pantries and the local soup kitchen. I felt deep respect when I listened to seniors talk about not having enough money for food, medicine, and living expenses, or a couple with two young children who lost their incomes in one devastating month. They admitted how they never thought they would have to depend on a pantry to feed their family and that they didn't want people to see them getting food, but couldn't allow their pride stop them from feeding their children. Being immersed in the Food Dignity project work was a unique chance to give 
honor to the heartbreaking realities of food insecurity experienced by people in my own community and across the country.

From that first exhilarating day of finding out the Food Dignity research project had been funded, I felt as though I was racing through one of the most powerful educational experiences of my life. $G$ reat lessons came to me because I said "yes" to being part of this project. When a community's residents do not have access to affordable, healthy food, it should unapologetically demand our attention. We must send a clear message that our food systems are failing to meet a basic human right- that is, the access to healthy affordable food. The collateral damage resulting from the absence of this right can be seen in poor health, suffering, and growing health costs. I was resolved that the problems of food insecurity were rooted in the economic realities of poverty, including underand unemployment. More importantly, I was resolved that solutions exist within the local food system.

At a regional conference in Binghamton, New Y ork, I learned how agriculture was a significant economic driver for the region. This led me to see the need for more local food production and the means to transport that food to food-insecure communities. This combination of increasing food availability and access along with business development and job creation within the food system became the clear path in my mind to how local community food systems can be fully sustainable. And if done well, true community access to institutions like Cornell University, Ithaca College, and Tompkins Cortland Community College could be an asset for supporting the local community efforts in business development, nutrition education, farming, food sciences, and more.

Throughout my tenure as a community organizer with the Food D ignity project, I envisioned ways to not only improve access to healthy foods, but to create opportunities for economic development in the food system. I saw no reason why people had to depend on food pantries for fresh food in such a lush agricultural landscape as what's all around us in Tompkins County.
I leveraged the Food Dignity resource package to offer minigrant, educational, and training opportunities, including paid research contracts with farmers, gardeners, and nonprofit agency leaders in Tompkins County. My efforts were driven by an important goal: to help develop their capacity for leadership to foster innovative solutions for areas of concern within the Tompkins County food system.

For me, emerging support for food system leadership development within the project was focused on people who represented low-income households and people of color. This approach was deliberate and intentional to address the common challenges I experienced and heard expressed by White liberal grassroots food activists at meetings. I felt constantly pummeled when attending public interest meetings, wondering where were the people of color and the low-income folks? In my experiences attending any kind of event with local food activists and organizers, I was usually one of few-if not the only- person of color present. Because the demographic makeup of the people organizing for food activism often didn't match the makeup of the people who were actually living with the challenges we were trying to address, I knew firsthand the valuable input that individuals actually living with the problems we were discussing could contribute to creating a culturally rich food system that values food dignity as the soil for a sustainable future.

As the Food Dignity project came to a close, all five community partners came together in celebration of the wealth of knowledge, wisdom, creativity, and profound experiences we shared throughout the five years. In that short span of time, the Food D ignity work represented the courage, critical thinking, compassionate understanding, and difficult interpersonal communication among people with different educational, socio-economic, cultural, and racial identities. The impact of this work cannot be captured in a short narrative; I invite you to explore how the Food Dignity project cultivated efforts to identify the value of dignity in the sustainability of our food system. Peace. 